\title{
VARIATION OF IMPURITY ELEMENT CONTENT, STRUCTURE AND PHASE COMPOSITION OF THE TEETH AT INFLAMMATORY ODONTOGENIC DISEASES
}

\author{
N.P.Dikiy ${ }^{1,3 *}$ E.P.Bereznyak ${ }^{1}$, S.N. Grigorov ${ }^{2}$, Yu. V.Lyashko ${ }^{1,3}$, \\ E.P.Medvedeva ${ }^{1,3}$, D. V.Medvedev ${ }^{1,3}$, L.P.Rekova ${ }^{2}$, Y.S.Hodyreva ${ }^{1}$ \\ ${ }^{1}$ National Science Center "Kharkiv Institute of Physics and Technology", 61108, Kharkiv, Ukraine; \\ ${ }^{2}$ Kharkiv National Medical University, 61022, Kharkiv, Ukraine; \\ ${ }^{3}$ V.N. Karazin Kharkiv National University, 6107r, Kharkiv, Ukraine
}

(Received April 3, 2018)

\begin{abstract}
Gamma-activation analysis on LUE NSC KIPT was used to measure macro-, microelements and ${ }^{224,226,228} \mathrm{Ra}$ in intact teeth and teeth with inflammatory odontogenic diseases. A comparative analysis of the phase composition of the teeth was carried out. It is shown that the size of apatite crystals in intact teeth is $\sim 3$ times higher than in teeth with acute odontogenic diseases. The latter indicates the presence of an amorphous phase of carbonate inclusions and structurally unbound water.
\end{abstract}

PACS: 87.64.km; 87.19.xh

\section{INTRODUCTION}

When studying the dental morbidity of an adult contingent in Kharkiv, a fairly high prevalence of odontogenic diseases was found. This may connect with the impact on the body of a number of environmental factors - atmospheric air, surface water, soil, etc. A significant role among these factors is played by the geochemical features of the Kharkiv region, in particular, the deficiency or large value of microelement content in environmental objects. At present, the problem of freshwater deficit and its quality is also topical, and therefore the assessment of the influence of the water factor on the human body is regarded as an obligatory component of a comprehensive analysis of environmental factors and their impact on human health. The consequences of odontogenic diseases are not limited only to the destruction of the masticatory apparatus, and its complicated forms often lead to inflammatory processes in the maxillofacial zone, allergization of the body, diseases of the ENT organs, digestive and excretory systems, provoke the development of rheumatic diseases, systemic diseases of the musculoskeletal system, infectious heart lesions, as well as other diseases of internal organs [1,2].

The purpose of this work was to study the content of elements, as well as the structure and phase composition of the teeth in acute odontogenic inflammatory diseases.

\section{MATERIALS AND METHODS}

The determination of trace elements content by gamma-activation analysis on LINAC NSC KIPT, as well as the crystalloptic method and IR spectroscopy method were used to study the physical properties of human teeth in inflammatory odontogenic diseases.

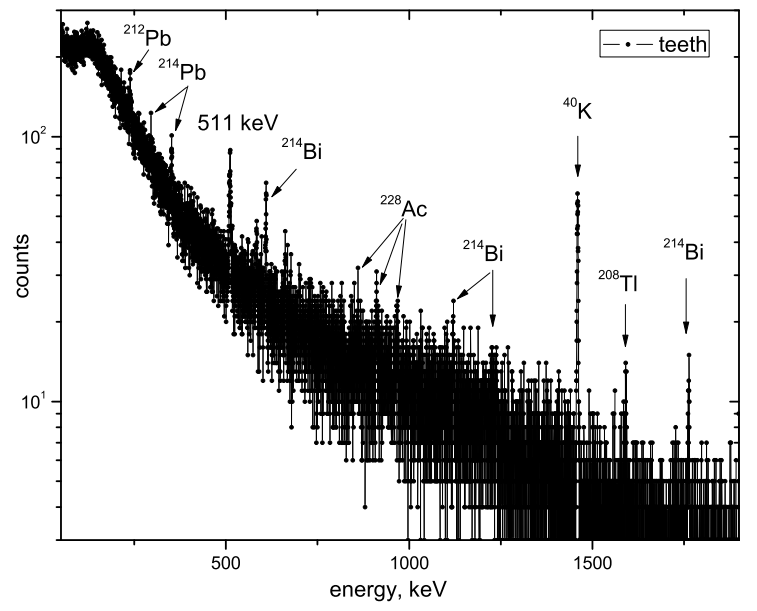

Fig.1. The spectrum of teeth

The material of the study was 170 extracted teeth (the age of patients from 40 to 70 years). After processing the teeth in flowing, distilled water and alcohol of different concentrations, it drying was carried out on filter paper. The $\gamma$-activation of the teeth samples, which were placed in aluminum canisters, was performed on the LINAC with an energy of $22 \mathrm{MeV}$,

${ }^{*}$ Corresponding author E-mail address: ndikiy@kipt.kharkov.ua 
followed by detection by a $\mathrm{Ge}(\mathrm{Li})$-detector with a volume of $50 \mathrm{~cm}^{3}$ with an energy resolution of $3.2 \mathrm{keV}$ in the $1332 \mathrm{keV}$ region (Fig.1).

IR spectrophotometer IKS-29 (LOMO) was used to record the absorption spectra in the infrared range. The spectra were recorded in the spectral range $4000 \ldots 400 \mathrm{~cm}^{-1}$ (mean infrared region) [3-5].

Powdered preparations obtained by grinding the samples in agate mortars to particle size $\sim 1 \ldots 10 \mu \mathrm{m}$ were studied. The samples were prepared in the form of transparent compressed tablets from a mixture of $\mathrm{KBr}$, which served as a matrix, and the test substance (in an amount of $1 \%$, a sample of $100 \mathrm{mg}$ ). Tablets had a rectangular shape and dimensions of $25 \times 5 \mathrm{~mm}$. The pressing pressure was $9200 \mathrm{~kg} / \mathrm{cm}^{2}$. To exclude the absorption bands of the matrix, a tablet of pure potassium bromide, previously dried at $180^{\circ} \mathrm{C}$ for 10 hours, was placed in the instrument comparison channel. Powders were pounded and mixed in a special closed box, pressing was performed just before the spectra were recorded. The grading was performed from the spectrum of polystyrene with known frequencies of absorption maxima. The correction at the average was $10 \ldots 5 \mathrm{~cm}^{-1}$.

Crystal-optical investigations were carried out on POLAM-L211, MIN-8 microscopes with the use of immersion liquids (IZH, OVIZ sets).

\section{RESULTS AND DISCUSSION}

A decrease of the content of $\mathrm{Ca}, \mathrm{K}, \mathrm{Mn}, \mathrm{I}, \mathrm{Cu}$, $\mathrm{F}$, an increase of $\mathrm{Zn}, \mathrm{Pb}, \mathrm{Cr}, \mathrm{Ni}, \mathrm{Al}$, as well as the unchanged content of $\mathrm{Sr}, \mathrm{Si}, \mathrm{B}$ were detected into teeth of patients with various inflammatory odontogenic diseases relative to intact teeth. The detection limit was near $10^{-5} \%$ by weight.

More clearly, the change in the content of elements in enamel for the norm and for inflammatory odontogenic diseases is presented in Tables 1 and 2 .

Table 1. The content of elements in enamel for norm and for inflammatory odontogenic diseases

\begin{tabular}{|l|c|c|}
\hline Substance & $\begin{array}{c}\text { Content in inflam- } \\
\text { matory odontoge- } \\
\text { nic diseases, } \%\end{array}$ & $\begin{array}{c}\text { Content in } \\
\text { norm, \% }\end{array}$ \\
\hline Calcium & $38.0 \pm 1.3$ & $26.0 \pm 0.8$ \\
\hline Fluorine & $0.95 \pm 0.03$ & $0.70 \pm 0.12$ \\
\hline Phosphorus & $17.1 \pm 1.2$ & $12.0 \pm 1.5$ \\
\hline Magnesium & $0.70 \pm 0.05$ & $1.7 \pm 0.8$ \\
\hline $\begin{array}{l}\text { Nonorganic } \\
\text { substance }\end{array}$ & $96.0 \pm 4.0$ & $51.1 \pm 1.6$ \\
\hline $\begin{array}{l}\text { Organic sub- } \\
\text { stance }\end{array}$ & $3.6 \pm 1.0$ & $4.9 \pm 1.2$ \\
\hline
\end{tabular}

From the presented values it can be seen that the pathological processes are most pronounced in the dentin of the tooth and consist in demineralization and in a sharp decrease in the concentration of calcium by $51.1 \%$ and phosphorus by $12.0 \%$. The process of demineralization also occurs in the enamel, which is associated with calcium loss by $12.3 \%$ and phosphorus loss by $4.5 \%$.
The generally recognized starting point for the appearance of odontogenic diseases is the progressive loss of mineral components of the tooth under the influence of various factors, for example, organic acids formed as a result of the activity of microorganisms $[6,7]$. Mineral substances of the tooth are represented mainly by crystals of apatites. The composition is represented by hydroxyapatite $(75 \%)$. Also, in addition, there are carbon apatites (19\%), chlorapatites $(4.4 \%)$ and fluorapatite $(0.66 \%)$. Less than $2 \%$ of the mass of permanent teeth are unorganized nonapatite forms. The main component of the tooth is hydroxyapatite $\mathrm{Ca}_{10}\left(\mathrm{PO}_{4}\right)_{6}(\mathrm{OH})_{2}$ and eightcalcium phosphate $\mathrm{Ca}_{8} \mathrm{H}_{2}\left(\mathrm{PO}_{4}\right)_{6} \times 5 \mathrm{H}_{2} \mathrm{O}$ with a $\mathrm{Ca} / \mathrm{P}$ molar ratio of 1.67 .

Table 2. The content of elements in dentin for norm and for inflammatory odontogenic diseases

\begin{tabular}{|l|c|c|}
\hline Substance & $\begin{array}{c}\text { Content in inflam- } \\
\text { matory odontoge- } \\
\text { nic diseases, \% }\end{array}$ & $\begin{array}{c}\text { Content in } \\
\text { norm, \% }\end{array}$ \\
\hline Calcium & $63.0 \pm 0.7$ & $12.3 \pm 2.6$ \\
\hline Fluorine & $0.90 \pm 0.09$ & $0.70 \pm 0.2$ \\
\hline Phosphorus & $18.3 \pm 0.5$ & $4.5 \pm 0.3$ \\
\hline Magnesium & $0.70 \pm 0.04$ & $1.9 \pm 0.07$ \\
\hline $\begin{array}{l}\text { Nonorganic } \\
\text { substance }\end{array}$ & $79.0 \pm 0.8$ & $35.0 \pm 0.2$ \\
\hline $\begin{array}{l}\text { Organic sub- } \\
\text { stance }\end{array}$ & $19.2 \pm 0.6$ & $65.0 \pm 0.5$ \\
\hline
\end{tabular}

The general formula of the apatite-like substance of the tooth can be modeled as $\mathrm{A}_{10}\left(\mathrm{BO}_{4}\right)_{6} \mathrm{X}_{2}$, where $\mathrm{A}-\mathrm{Ca}^{2+}$ can be replaced by $\mathrm{Cr}^{2+}, \mathrm{Ba}^{2+}, \mathrm{Cd}^{2+}, \mathrm{Mg}^{2+}$, $\mathrm{B}-\mathrm{P}^{3-}$ by $\mathrm{As}^{3-}, \mathrm{Si}^{3-}$, and $\mathrm{X}-$ by $\mathrm{F}^{-}, \mathrm{OH}^{-}$, hydroxonium $\left(\mathrm{H}_{3} \mathrm{O}^{+}\right)$and $\mathrm{ClCO}_{2}$ or another element with similar properties, these substitution reactions have been termed isomorphic substitution. As a result of this substitution, the $\mathrm{Ca} / \mathrm{P}$ ratio decreases due to a decrease in the proportion of calcium in the crystal. The reaction can be described by the following equation:

$\mathrm{Ca}_{10}\left(\mathrm{PO}_{4}\right)_{6}(\mathrm{OH})_{2}+\mathrm{Mg}^{2+} \rightarrow \mathrm{Ca}_{9} \mathrm{Mg}\left(\mathrm{PO}_{4}\right)_{6}(\mathrm{OH})_{2}+$ $\mathrm{Ca}^{2+}$.

Another isomorphic substitution in the hydroxyapatite crystal, represented by the formula:

$\mathrm{Ca}_{10}\left(\mathrm{PO}_{4}\right)_{6}(\mathrm{OH})_{2}+\mathrm{F}^{+} \rightarrow \mathrm{Ca}_{10}\left(\mathrm{PO}_{4}\right)_{6} \mathrm{~F}(\mathrm{OH})+\mathrm{OH}^{-}$.

As a result of this reaction, hydroxyapatite transforming to fluorapatite, which has a more pronounced resistance to acid dissolution than hydroxyapatite. It is this substitution that explains the preventive effect of fluoride.

The next factor affecting the change in the composition of hydroxyapatite is the presence of free vacancies in the crystal lattice. The basis of this phenomenon is the presence of a vacant place in the crystal lattice, which is replaced by one of the ions. When crystals are formed, as a result of various transformations, individual places in the crystal lattice remain 
unoccupied. Also, free places and isomorphous substitutions can arise in the crystal under temperature and other physical, and also chemical effects on it, in particular, when interacting with organic acids.

The presence of isomorphous substitutions and the formation of vacancies lead to significant structural disturbances and changes in the properties of the crystals and the hydroxyapatite substance as a whole. Due to the formation of free places, the coefficient $\mathrm{Ca} / \mathrm{P}$ decreases and a number of other irregularities occur. In crystals with a large number of vacancies, the ability to surface reactions sharply increases. The reason of this is easy to understand, considering the formulas of ten- and eight-calcium hydroxyapatite:

$$
\begin{aligned}
& {\left[\mathrm{Ca}_{10}\right]^{20+}\left[\left(\mathrm{PO}_{4}\right)_{6}(\mathrm{OH})_{2}\right]^{20-}} \\
& \text { and }\left[\mathrm{Ca}_{8}\right]^{16+}\left[\left(\mathrm{PO}_{4}\right)_{6}(\mathrm{OH})_{2}\right]^{20-} .
\end{aligned}
$$

The first formula shows that the number of charges of positive and negative ions is balanced, and in the second case, the negative ion charge is greater. Thus, the crystals of such hydroxyapatite will be negatively charged. In the case of vacancies of negatively charged ions, the crystallite surface acquires an excess positive charge. The consequence of unbalanced of hydroxyapatite charge will be its increased reactivity, especially connected with surface reactions [8]. To reduce excess surface energy, the charged hydroxyapatite will sorb on its surface of ions that neutralize the excess charge. Consequently, the presence of vacancies in the crystal lattice can cause the increased reactivity of hydroxyapatite and the high intensity of the adsorption process on the crystals.

Each hydroxyapatite crystal is covered with a hydrated shell, $\sim 1 \mathrm{~nm}$ thick, and the crystals are located $2.5 \mathrm{~nm}$ apart [9]. These data are very important since it explain the mechanism of isoionic and heteroionic substitution in crystals, which ensures the maintenance of the tooth's homeostasis, and the reason for the change in its composition and properties, in the process of remineralization in the formation of odontogenic diseases.

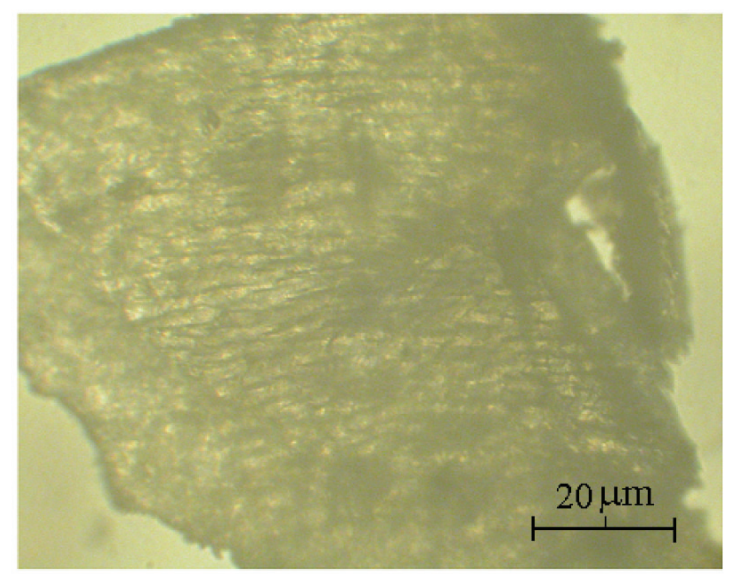

Fig.2. A microphotograph of an immersion preparation of healthy tooth tissue. Without analyzer. Large grain of hydroxyapatite
Crystals of hydroxyapatite have the ability to physicochemical exchange. This fact indicates that crystals, striving for stability, are capable of changing, while their composition and properties vary depending on the composition of the hydrate layer, which in turn depends on the composition of the solution in contact with the crystals of hydroxyapatite [10]. These data are confirmed by the results of crystal-optical and spectral-optical analyzes.

Fig. 2 shows a microscopic sample, which is a large-grained clastic mass consisting of transparent grains of 30 to 150 microns in size. Individual grains have a pronounced banded texture (Fig.3).

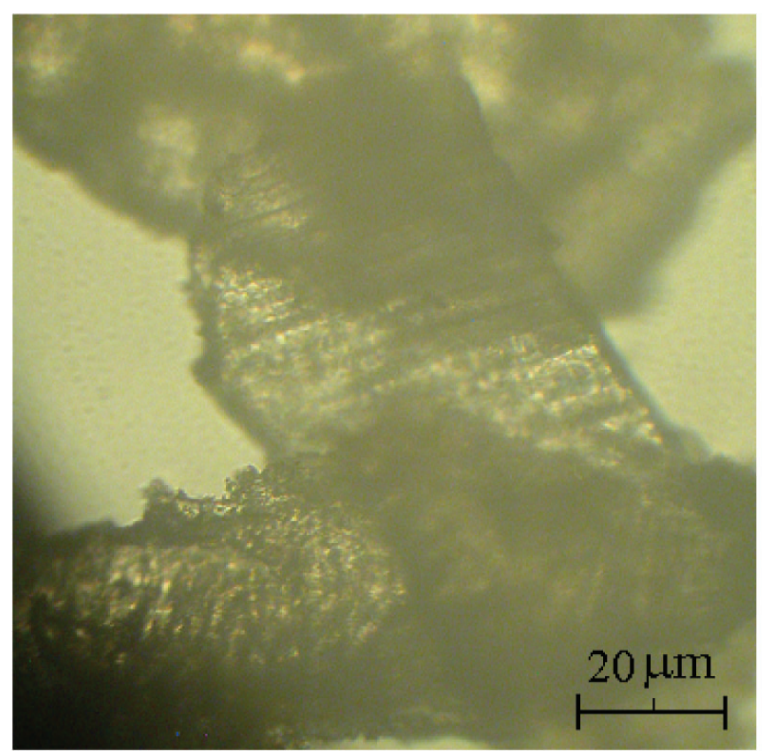

Fig.3. A microphotograph of an immersion preparation of healthy tooth tissue. Without analyzer. Grains with a pronounced striated texture

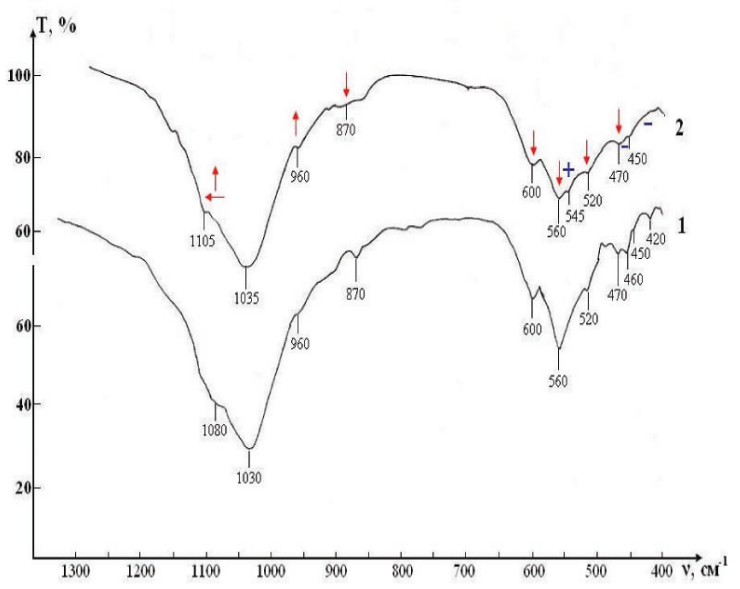

Fig.4. IR absorption spectra of a healthy and diseased tooth in the range of $400 \ldots 1300 \mathrm{~cm}^{-1}$ : arrow to down - decrease in the intensity of the band; up arrow - increase in the intensity of the band; left arrow - shift of the band; + appearance of a new band, - disappearance of the band

In the IR spectra of a healthy tooth, the bands corresponding to different types of vibrations of the 
main structural fragments of the inorganic component of the tooth tissue appear: orthophosphoric groups $\mathrm{PO}_{4}{ }^{3-}$, molecular water, hydroxyl groups and carbonate ions $\mathrm{CO}_{3}{ }^{2-}$, replacing the $\mathrm{PO}_{4}{ }^{3-}$ ions (Figs.4,5, curve 1). Identification of bands in the spectrum is given in Table 1 . Judging by the shape and position of the bands in the spectrum, the phosphate material of the tooth is represented by minerals of the apatite group (apatite, fluorapatite, hydroxyapatite, carbonated hydroxyapatite). The bands have sharp maxima, which indicates a high degree of crystallinity of the substance and its structural ordering.

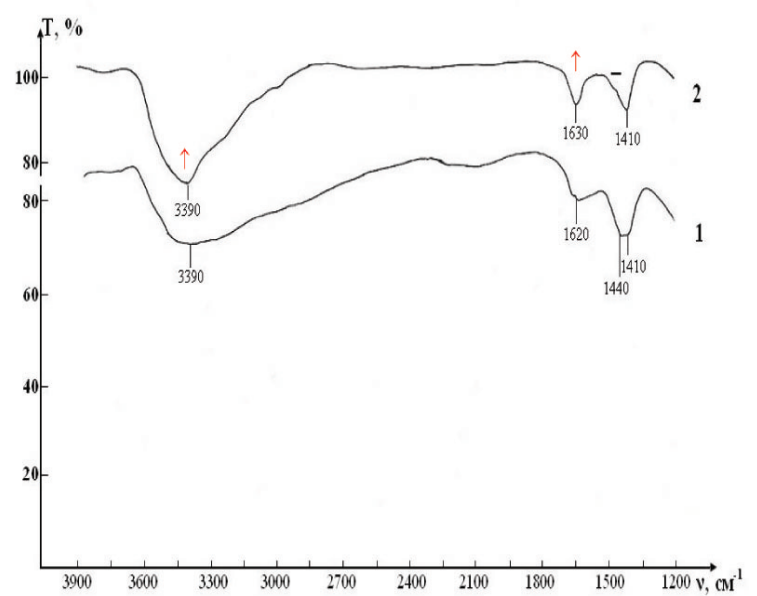

Fig.5. IR absorption spectra of a healthy and diseased tooth in the range $1200 \ldots 4000 \mathrm{~cm}^{-1}$

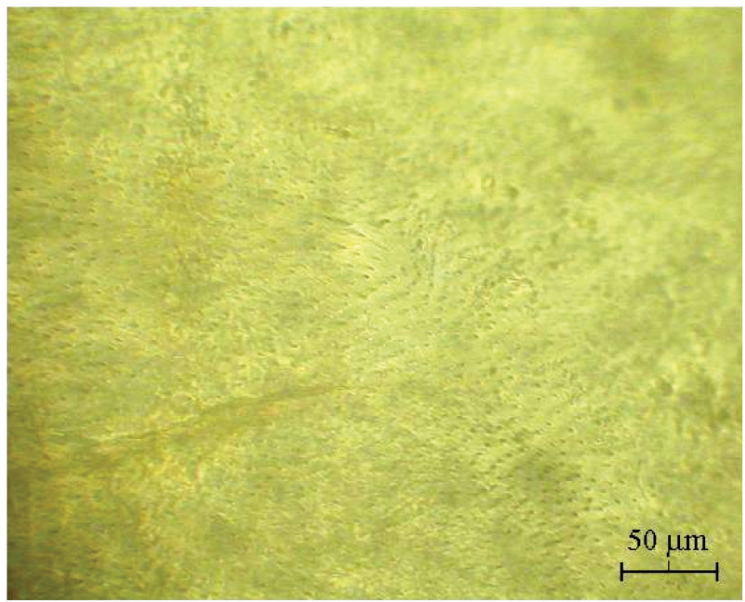

Fig.6. A microphotograph of an immersion preparation of the tissue of a diseased tooth.

Without analyzer. A large semitransparent grain of yellow color containing a needle-like inclusion of the carbonate phase and a number of bubbles oriented along the cleavage planes

In contrast to the tissue of a healthy tooth, which, according to crystal-optical studies, is practically single-phase and completely consists of a crystalline clastic mass, the tissue of the diseased tooth consists of three main phases (Figs.6-8):

1. Semi-transparent large grains of dark gray color with a large number of inclusions (bunches, needles, bubbles, etc.)
2. Transparent colorless grains, the size of which is from 3 to 70 microns with a very thin banded texture.

3. Grains of a poorly crystallized carbonate phase of yellow-orange color and carbonate inclusions and sprouts in round grains.

In the IR spectrum of the patient's tooth tissue, the same bands are present as in the tissue of a healthy tooth (see Figs.4,5 curve 2). However, the intensity of the bands of hydroxyapatite corresponding to the valence and deformation O-P-O vibrations in the tetrahedra of $\mathrm{PO}_{4}{ }^{3-}$ - decreased significantly.

Table 3. Identification of bands in IR-spectra of a tooth fabric: sp - sharp, sh - shoulder; $m$ - medium;

$w$ - weak; vs - very strong; vw - very weak; s strong; inf - inflection; $b$ - broad; ${ }^{*}-$

hydroxyapatite;

\begin{tabular}{|c|c|c|}
\hline $\begin{array}{l}\text { Intact } \\
\text { tooth, } \\
\mathrm{cm}^{-1}\end{array}$ & $\begin{array}{l}\text { Affected } \\
\text { tooth, } \\
\mathrm{cm}^{-1}\end{array}$ & Assignment of band \\
\hline $420 \mathrm{sp}, \mathrm{w}$ & & Vibrations Me-P \\
\hline $450 \mathrm{sh}$ & $450 \mathrm{sh}$ & Vibrations Me-P \\
\hline $460 \mathrm{~m}$ & & $\begin{array}{l}\text { Bending vibrations } \mathrm{O}- \\
\mathrm{P}-\mathrm{O} \text { in } \mathrm{PO}_{4}{ }^{3-}\end{array}$ \\
\hline $470 \mathrm{~m}$ & $470 \mathrm{w}$ & $\begin{array}{l}\text { Bending vibrations O- } \\
\mathrm{P}-\mathrm{O} \text { in } \mathrm{PO}_{4}{ }^{3-}\end{array}$ \\
\hline $520 \mathrm{sh}$ & $520 \mathrm{vw}$ & $\begin{array}{l}\text { Bending vibrations O- } \\
\mathrm{P}-\mathrm{O} \text { in } \mathrm{PO}_{4}{ }^{3-}\end{array}$ \\
\hline $560^{*} \mathrm{~s}, \mathrm{sp}$ & $560^{*} \mathrm{w}$ & $\begin{array}{l}\text { Stretching vibrations } \\
\mathrm{O}-\mathrm{P}-\mathrm{O} \text { in } \mathrm{PO}_{4}{ }^{3-}\end{array}$ \\
\hline $600^{*} \mathrm{sp}, \mathrm{m}$ & $600^{*} \mathrm{w}$ & $\begin{array}{l}\text { Stretchin vibrations } \mathrm{O}- \\
\mathrm{P}-\mathrm{O} \text { in } \mathrm{PO}_{4}{ }^{3-}\end{array}$ \\
\hline $870 \mathrm{w}$ & $870 \mathrm{vw}$ & $\begin{array}{l}\text { Bending vibrations O- } \\
\mathrm{C}-\mathrm{O} \text { in } \mathrm{PO}_{4}{ }^{3-} \text {, substi- } \\
\text { tution in } \mathrm{PO}_{4}{ }^{3-}\end{array}$ \\
\hline $960^{*} \mathrm{sh}, \mathrm{w}$ & $960^{*} \mathrm{w}$ & $\begin{array}{l}\text { Fully symmetrical va- } \\
\text { lency oscillations P-O } \\
\text { in } \mathrm{PO}_{4}{ }^{3-}\end{array}$ \\
\hline $1030^{*} \mathrm{vW}$ & $1030^{*} \mathrm{w}$ & \begin{tabular}{ll} 
Asymmetric & \multicolumn{2}{r}{ valency } \\
oscillations & $\mathrm{P}-\mathrm{O}$ in \\
$\mathrm{PO}_{4}{ }^{3-}$ &
\end{tabular} \\
\hline $1080^{*} \mathrm{sh}$ & $1105^{*} \mathrm{w}$ & \begin{tabular}{ll} 
Asymmetric & \multicolumn{2}{c}{ valency } \\
oscillations & $\mathrm{P}-\mathrm{O}$ in \\
$\mathrm{PO}_{4}{ }^{3-}$ &
\end{tabular} \\
\hline $\begin{array}{l}1410,1440 \\
\text { doublet } \\
\mathrm{m}, \mathrm{b}\end{array}$ & $1410 \mathrm{~m}, \mathrm{sp}$ & $\begin{array}{l}\text { Mode of asymmetric } \\
\text { stretching vibrations of } \\
\mathrm{C}-\mathrm{O} \text { in } \mathrm{CO}_{3}{ }^{2-}\end{array}$ \\
\hline $1620 \mathrm{w}, \inf$ & $1630 \mathrm{~m}$ & $\begin{array}{l}\text { Bending vibrations } \mathrm{H} \text { - } \\
\mathrm{O}-\mathrm{H} \text { in } \mathrm{H}_{2} \mathrm{O}\end{array}$ \\
\hline $\begin{array}{l}3390 \\
\mathrm{w}(\sim 15 \%)\end{array}$ & $\begin{array}{l}3390 \\
\mathrm{~m}(\sim 30 \%)\end{array}$ & $\begin{array}{l}\text { Stretching vibrations } \\
\mathrm{OH}^{-} \text {in } \mathrm{H}_{2} \mathrm{O}\end{array}$ \\
\hline
\end{tabular}

The intensity of the vibrations of the P-O bonds remains unchanged. Some small peaks completely disappeared. In addition, the intensity of the carbonate phase band $\left(870 \mathrm{~cm}^{-1}\right)$ decreases and instead of the characteristic doublet (1410 and $1440 \mathrm{~cm}^{-1}$ ) for the crystalline carbonate, one narrow band $1410 \mathrm{~cm}^{-1}$ is formed. Most likely, this is due to the 
fact that the carbonate phase in this sample is an amorphous carbonate, mainly in the form of $\mathrm{CaCO}_{3}$. The intensity of the bands associated with molecular water (3390 and $1630 \mathrm{~cm}^{-1}$ ) sharply increased. This can be caused by an increase in the amount of structurally unbound water, which is present in the form of bubbles in the voids of the structure of this substance, which is confirmed by the data of crystaloptical analysis (Fig.6).

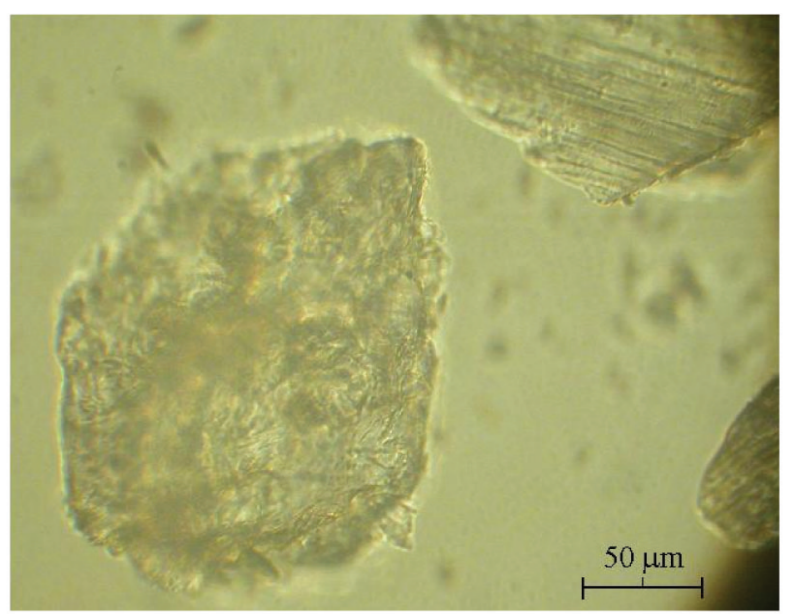

Fig.7. A microphotograph of an immersion preparation of the tissue of a diseased tooth.

Without analyzer. A round grain containing orange-yellow carbonate sprouts, and a transparent grain with a banded texture

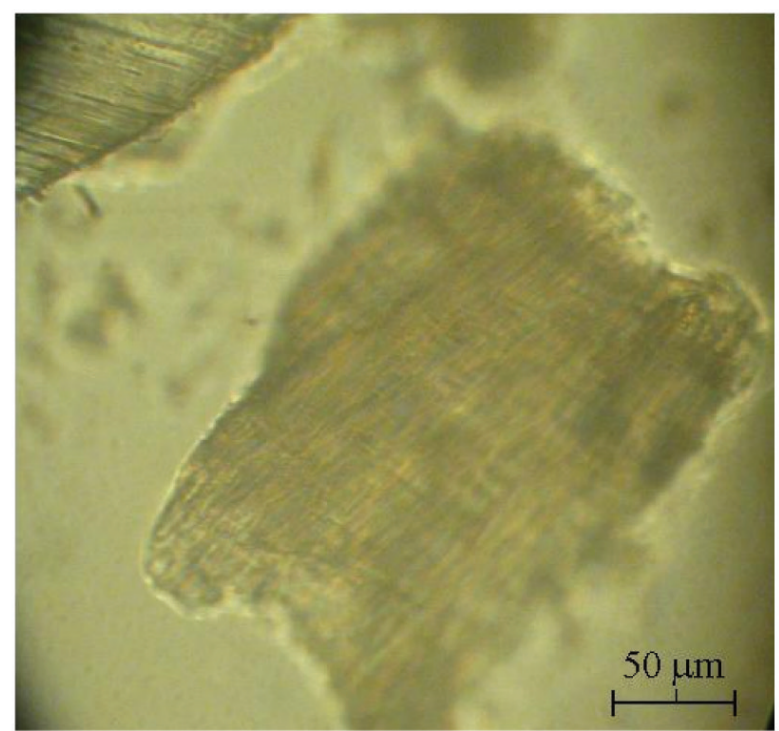

Fig.8. A microphotograph of an immersion preparation of the tissue of a diseased tooth. Without analyzer. Semitransparent grain with different inclusions

Our studies were aimed at establishing the patterns of changes in the content of elements, as well as the structure and phase composition of teeth in odontogenic diseases. It is shown that demineralization is the trigger mechanism of this disease, but at the initial stages, it proceeds asymptomatically, without clinically manifesting itself. The first structural changes in the hard tissues of the tooth occur at the time of the disruption of the structure of the organic matrix and become irreversible. Most often, this can occur when the actinides are introduced into the body through the air, water and food chains, the decay of which, as a rule, is accompanied by the escape of the $\alpha$-particles. Actinides also exhibit high chemical activity, participate in oxidation-reduction reactions, diffusion processes.

${ }^{226} \mathrm{Ra}$ activity of unirradiated teeth with odontogenic diseases is $1.2 \cdot 10^{-2} \mathrm{~Bq} / \mathrm{g}$. The intake of $224,226,228 \mathrm{Ra}$ in our case is not due to the decay of uranium and thorium. The content of $\mathrm{U}$ and $\mathrm{Th}$ in the teeth is $1 \ldots 100 \mathrm{ppb}$. The activity of ${ }^{226} \mathrm{Ra}$ in patients with odontogenic diseases is $15 . .40$ times higher than the content of ${ }^{226} \mathrm{Ra}$ in intact teeth [11-13].

The content of ${ }^{228} \mathrm{Ra}$ in the teeth is $3.910^{-16} \mathrm{~g} / \mathrm{g}$, and the content of ${ }^{226} \mathrm{Ra}$ is $3.3210^{-13} \mathrm{~g} / \mathrm{g}$. The inhabitants of Kharkiv receive drinking water mainly from the Dnieper (Kremenchug reservoir).

\section{CONCLUSIONS}

1. A set of methods for conducting a comparative analysis of the content of macro- and microelements in intact teeth and teeth in odontogenic inflammatory diseases was used. The imbalance in the content of $\mathrm{Ca}, \mathrm{K}, \mathrm{Mn}, \mathrm{I}, \mathrm{Cu}, \mathrm{F}, \mathrm{Zn}, \mathrm{Pb}, \mathrm{Cr}, \mathrm{Ni}, \mathrm{Al}$, etc. is shown.

2. Accumulation of ${ }^{224,226,228} \mathrm{Ra}$ in the teeth with odontogenic pathology was detected. The content of these actinides is 25 times higher than the average value of these radionuclides in intact teeth.

3. Spectral-optical data of a healthy tooth's tissue indicate an ordered crystalline structure consisting of apatite group minerals containing an insignificant amount of molecular water, hydroxyl groups and carbonate ions of $\mathrm{CO}_{3}{ }^{2-}$, replacing the $\mathrm{PO}_{4}{ }^{3-}$-ions. The tissue of the diseased tooth consists of several phases and contains both a crystalline component in the form of an apatite phase with a disordered structure and amorphous carbonate phases, and is also characterized by a significant content of structurally unbound water. The increase in the amount of water is due to the looseness of the structure and a large number of voids in it.

4. The results of the research are necessary to understand the pathogenesis of this disease and theirs must be taken into account when preparing treatment measures for individual treatment.

\section{References}

1. V. Gorecka, S. Suiiborski, T. Biskupski. Direct pulp capping with a dentin adhesive resin system in children's permanent teeth after traumatic injuries: case reports // Quintessence Int. 2000, v.3, p.241-248.

2. B.A.Burt. Concepts of risk in dental public health // Community Dent. Oral Epidemiol. 2005, v.33, p.240-247. 
3. L. Votjakov, D.V. Kiselyov, J.V. Shchapova, et al. Physical and chemical characteristics of the fossil bone rests of mammals and a problem of an estimation of their relative age, part 2, Ekaterinburg, publishing house "Goshchitsky", 2009, 82 p. (in Russian).

4. The infrared spectra of minerals/ Edited by V.C. Farmer. Mineralogical society, Monograph 4, London SW7 5HR, 1974, 539 p.

5. E. Larsen, G.Berman. Definition transparent minerals under a microscope. M.: Publishing house "Bowels", 1965, 464 p. (in Russian).

6. V.V. Voronin, V.K. Leontev, V.T.Shestakov. Two models of a substantiation of an aetiology of caries from a position of the system approach // Stomatology, 2001, N6, p.15-17 (in Russian).

7. E.M. Volkov. Remineralization efficiency of means BV at caries of a teeth in a stage of a white stain // Cathedra, 2007, N1, p.32-34 (in Russian).

8. T.V. Bavykina, T.Y. Pavlova Comparative an estimation of mineral structure and an ultramicrostructure of a tooth tissue in norm and at caries // Modern high technologies, 2009, N12, p.15-18 (in Russian).

9. E. Landy, G. Celotti, G. Logroscino, et al. Carbonated hydroxy apatite as bone substitute // J. Eur. Cer. Soc. 2003, v.23, p.2931-2937.

10. Jing Xue, L. Zhang, L. Zou, Y. Liao, et al. Highresolution X-ray microdiffraction analysis of natural teeth // J. Synchrotron Rad. 2008, v.15, p.235-238.

11. N.P. Dikiy, Yu.V. Lyashko, E.P. Medvedeva, et al. Deposit of bone-seeking radionuclides in teeth of patients with odontogenic diseases // PAST. Ser.: "NPI"(105), 2016, N5(67), p.55-58.

12. S.S. Hummadi. Determination of uranium concentration in teeth female samples using fission tracks in CR-39 from different countries // J. AlNahrain Univer. 2010, v.13(4), p.127-131.

13. G.R.Prado, J.D.T. Arruda-Neto, J.E.S. Sarkis, et al. Evaluation of uranium incorporation from contaminated areas using teeth as bioindicators - a case study // Rad. Prot. Dosimetry. 2008, v.130, N2, p.249-252.

\title{
ИЗМЕНЕНИЕ СОДЕРЖАНИЯ ПРИМЕСНЫХ ЭЛЕМЕНТОВ, СТРУКТУРЫ И ФАЗОВОГО СОСТАВА ЗУБОВ ПРИ ОСТРЫХ ОДОНТОГЕННЫХ ВОСПАЛИТЕЛЬНЫХ ЗАБОЛЕВАНИЯХ
}

\author{
Н.П. Дикий, Е.П. Березняк, С.Н. Григоров, Ю. В. Ляшко, Е. П. Медведева, \\ Д. В. Медведев, Л. П. Рекова, Ю. С. Ходирева
}

Гамма-активационный анализ на ЛУЭ ННЦ ХФТИ был использован для измерения макро-, микроэлементов и ${ }^{224,226,228} \mathrm{Ra}$ в интактных зубах и зубах с острыми одонтогенными заболеваниями. Проведен сравнительный анализ фазового состава зубов. Показано, что размер кристаллов апатита в интактных зубах в $\sim 3$ раза больше, чем в зубах при острых одонтогенных заболеваниях. В последних отмечено наличие аморфной фазы карбонатных включений и структурно несвязанной воды.

\section{ЗМІНА ВМІСТУ ДОМІШКОВИХ ЕЛЕМЕНТІВ, СТРУКТУРИ І ФАЗОВОГО СКЛАДУ В ЗУБАХ ПРИ ГОСТРИХ ОДОНТОГЕННИХ ЗАПАЛЬНИХ ЗАХВОРЮВАННЯХ}

\section{М.П. Дикий, О.П. Березняк, С. М. Григоров, Ю. В. Ляшко, О. П. Медведєва, Д. В. Медведєв, Л. П. Рекова, Ю. С. Ходирєва}

Гамма-активаційний аналіз на ЛПЕ ННЦ ХФТІ був використаний для вимірювання макро-, мікроелементів i ${ }^{224,226,228} \mathrm{Ra}$ в інтактних зубах і зубах з гострими одонтогенними захворюваннями. Проведено порівняльний аналіз фазового складу зубів. Показано, що розмір кристалів апатиту у інтактних зубах у 23 рази більше, ніж в зубах при гострих одонтогенних захворюваннях. В останніх відзначено наявність аморфної фази карбонатних включень і структурно незв'язаної води. 